\title{
Measuring of beat up force on weaving machines
}

\author{
Martin Bílek $^{1 \mathrm{a}}$, Eva Moučková ${ }^{2}$, Josef Skřivánek $^{1}$ and Petr Tumajer ${ }^{2}$ \\ ${ }^{1}$ Technical University of Liberec, Dept. of Textile Machine Design, Studentská 2, 46117 Liberec 1, Czech Rep. \\ ${ }^{2}$ Technical University of Liberec, Department of Textile Technologies, Studentská 2, 46117 Liberec 1, Czech Rep.
}

\begin{abstract}
The textile material (warp) is stressed cyclically at a relative high frequency during the weaving process. Therefore, the special measuring device for analysis of beat up force in the textile material during the weaving process, has been devised in the Weaving Laboratory of the TUL. This paper includes a description of this measuring device. The experimental part includes measurements results for various materials (PES and VS) and various warp thread densities of the produced fabric.
\end{abstract}

\section{Introduction}

Fabric in a weaving machine is formed in a discontinuous process based on a cyclic repetition of individual phases of the weaving cycle: opening a shed, interlacing the weft, beat up the weft and closing the shed. This interlaces two mutually perpendicular yarn systems (warp and weft) [5].

Opening a shed and applying the beat up force results in the warp thread being stretched. Because of the high weaving frequencies of modern machines, the warp threads are subjected to cyclic stressing of relatively high frequency [4].

\section{Beat up process and its force quantities}

A loom is capable of producing fabrics of different weft thread density, i.e. fabrics with varying number of weft threads per centimetre of their length. The number of wefts weaved per unit of time depends on the weaving frequency (machine speed), and the required weft thread density is set by the speed of the fabric being taken up. The fabric is taken up by rough rollers powered by a separate motor. Modern looms allow information

concerning the required weft thread density to be uploaded to the control computer which will then set the required take-up speed for the specified loom speed (revolutions of the motor driving the rough rollers) to achieve the required weft thread density [5]. Thus the required weft thread density is set exclusively on the basis of geometric parameters.

The resultant fabric structure including its weft thread density is formed during the beat up process. During this process a mutual force interaction takes place between the weft, the warp system and the fabric. When making a fabric with higher density weft threads, the warp threads due to the beat up stretch and the fabric is "shortened" by value $X$, i.e. the beat up results in an increase of the tensile force in the warp threads $Q_{1}$ and a decrease of the tensile strength in the fabric $\mathrm{Q}_{2}$. [6]

The force acting on the fabric face at beat up, i.e. the so called beat up force $F_{b}$, can then be determined as a difference between the tensile force in the warp threads Q1 and the tensile force in the fabric $\mathrm{Q}_{2}$ :

$$
F_{P}=Q_{1}-Q_{2}
$$

The beat up force induces a reaction in the fabric, known as weaving resistance $\mathrm{R}$ :

$$
R=F_{P}
$$

Figure 1: Textile weaving phases

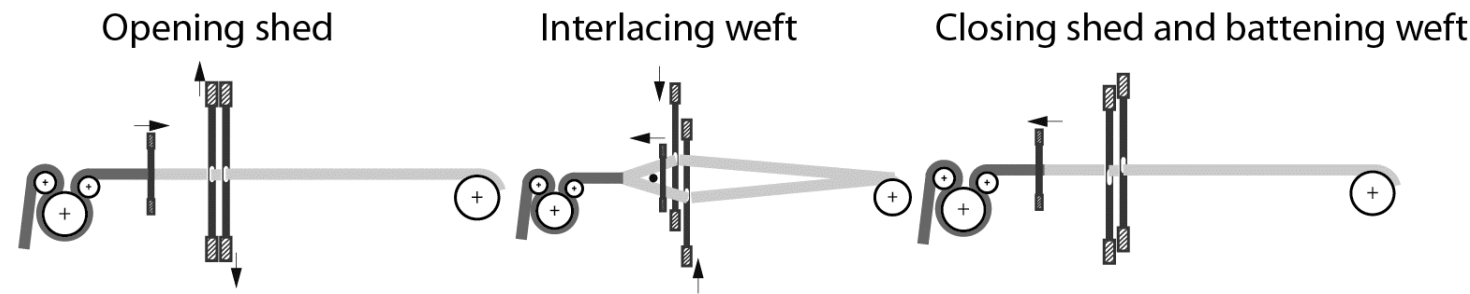

\footnotetext{
a Corresponding author: martin.bilek@tul.cz
}

C) The Authors, published by EDP Sciences. This is an open access article distributed under the terms of the Creative Commons Attribution License 4.0 (http://creativecommons.org/licenses/by/4.0/). 
Figure 2: Example of tensile forces in the warp as a function of time during the weaving process (machine speed: $500 \mathrm{rpm}$ )

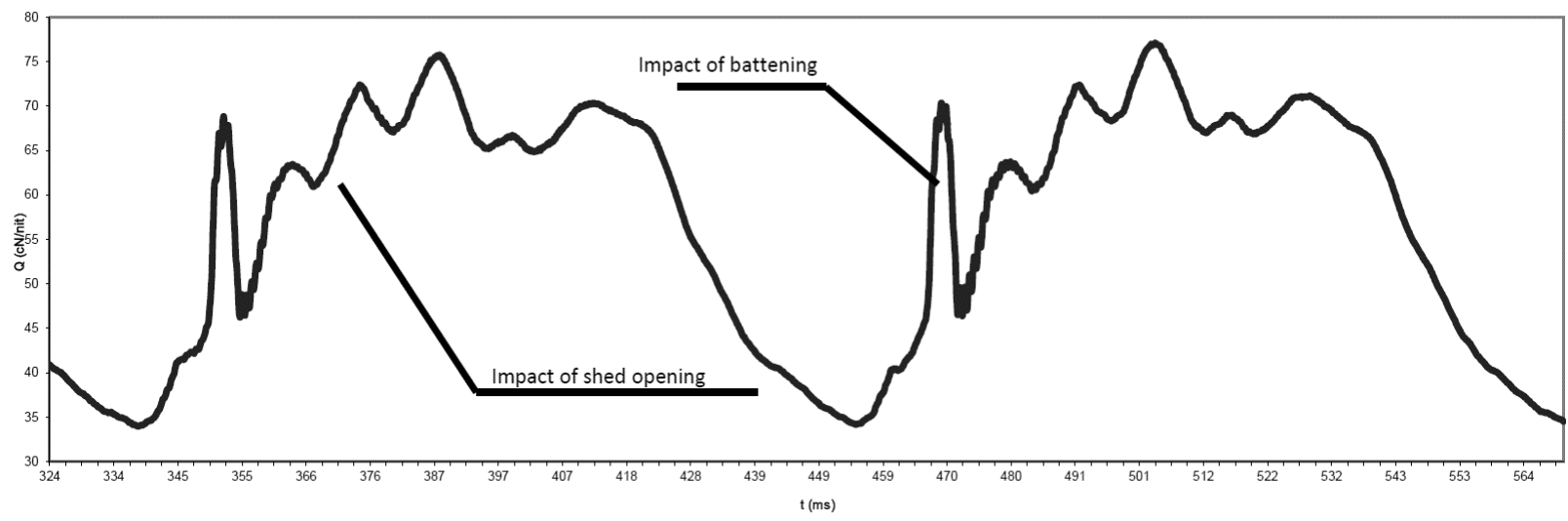

Figure 3: Loom fabric taking-up and setting weft thread density

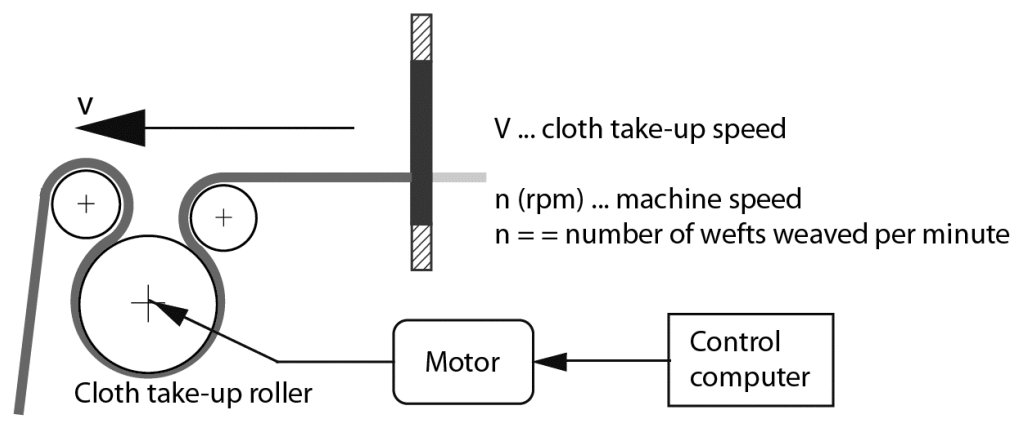

Figure 4: Situation at beat up

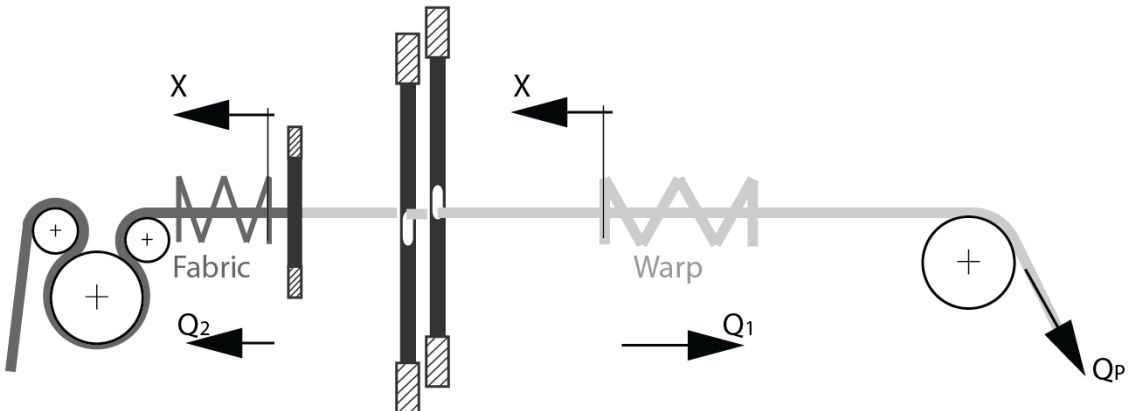

$X$... stretching of the warp threads and shortening of the fabric, $Q_{2} \ldots$ tensile force in the fabric, $\mathrm{Q}_{1} \ldots$ tensile force in the warp, Qp ... prestressing set by the let-of motion

Therefore the beat up force and the weaving resistance can be determined as a difference between the tensile force in the warp threads and that in the fabric during the beat up process. This article describes experimental measurements of these quantities. Presented are the results of measurements for various warp thread densities of produced fabrics, as well as various materials being used.

\section{Beat up force measuring device}

The tensile force in the warp threads and in the fabric was simultaneously measured on a Gamma-8-R rapier loom (manufacturer: Picanol) using strain gauges. The signal received from these stain gauges was digitised and then processed on Waweon equipment $[1,8]$.
Tensile force in the warp threads was measured by a standard strain gauge sensor which was for this purpose designed by VÚTS Liberec. This sensor was inserted into the warp thread system between the warp beam and heddles.

Tensile force in the fabric was measured by a specially designed sensor. A hard aluminium beam was placed across the entire width of the weaving machine. A strain gauge was positioned between the beam and the fabric, whose one end was fastened to the beam and a "scanning rod" was attached to the other end. This rod was pushed into the fabric (the size of the scanning rod girding determines the equipment's sensitivity). To ensure that the breaking of the fabric in the vicinity of the point of measurement was equal, dimension-wise identical jigs 
had to be located on the right and the left hand side of the strain gauge.

Both sensors were calibrated to ensure that the value of the output signal determined tensile force in $\mathrm{cN}$ in a single warp thread. Tensile forces in the warp threads and in the fabric as a function of time can be illustrated in the Waweon equipment, and these values can then be exported to text files. Further processing is carried out in an Excel spread sheet.

Figure 5: Positioning of sensors and detectors on the loom

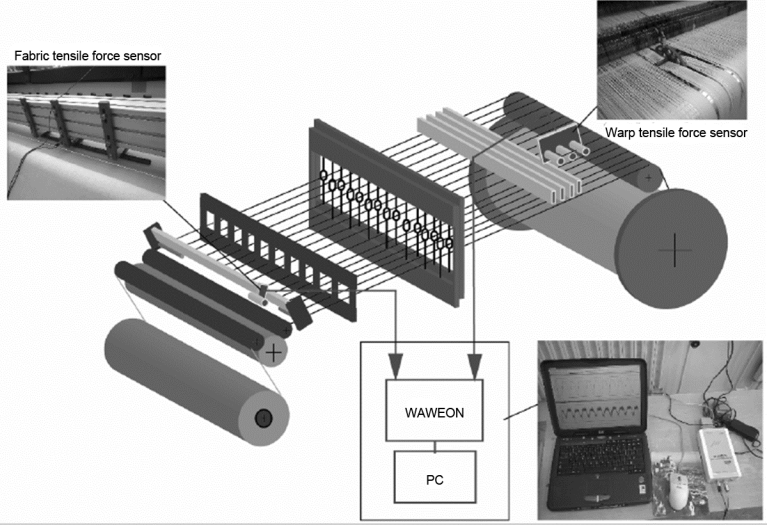

Figure 6: Fabric tensile force sensor

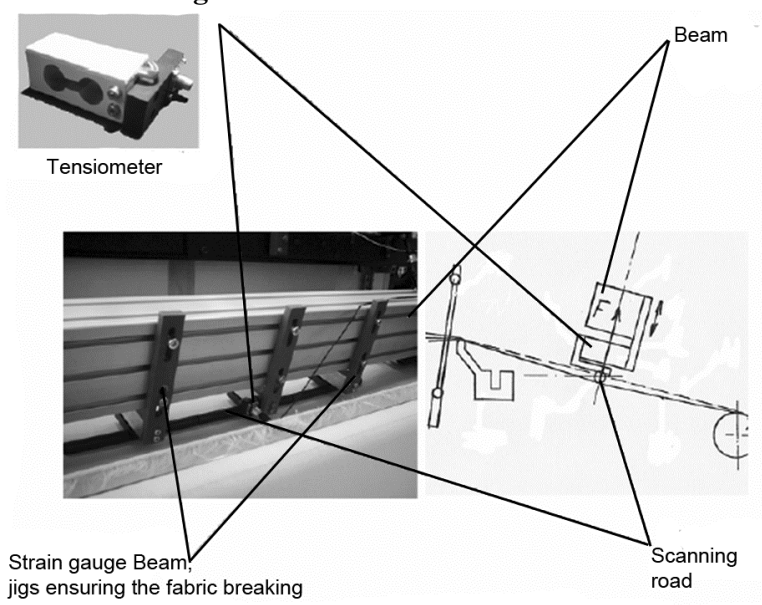

\section{Example of measurement results}

The results of weaving resistance measurements for various materials (PES and VS) and various warp thread densities of the produced fabrics (from 12 threads per $\mathrm{cm}$ to 22 threads per $\mathrm{cm}$ ) are presented in this article. The measurements were performed with the machine running at a stabilised speed of $300 \mathrm{rpm}$.

The figure below is an example of the results of measurements taken at weft density 18 threads/cm and material PES. Illustrated in a common coordinate system are tensile forces in warps $Q_{1}$ and tensile forces in the fabric $\mathrm{Q}_{2}$. Presented time interval contains 4 weaving cycles.

Subsequently using an Excel spread sheet, the difference between the tensile force in warps $\mathrm{Q}_{1}$ and in the fabric $\mathrm{Q}_{2}$ can be expressed, where the difference represents the beat up force $F_{p}$ and weaving resistance $R$, respectively. The weaving resistance as a function of time is illustrated in the figure no 8:

Furthermore, readings of values of maximum weaving resistance were taken for 8 beat up cycles, and these values were statistically processed. The values of maximum weaving resistance $\mathrm{R}_{\max }$, standard deviation and a 95\% confidence interval for all performed measurements are presented in the table below.

Table 1. Measurement conditions

\begin{tabular}{|c|c|c|}
\hline Speed (rpm) & \multicolumn{2}{|c|}{300} \\
\hline Reed width (cm) & \multicolumn{2}{|c|}{178} \\
\hline Warp density (threads/cm) & \multicolumn{2}{|c|}{ Plane } \\
\hline Fabric weave & $2 \times 25$ tex & $2 \times 25$ tex \\
\hline Material in warp and weft & $100 \%$ POP & $100 \%$ VS \\
\hline Let off motion (cN/thread) & 53 & 42 \\
\hline Weft density (threads/cm) & $12,14,16$, & $12,14,16$, \\
$18,20,22$ & $18,20,22$ \\
\hline
\end{tabular}

Table 2. The values of maximum weaving resistance

Material: 2 x 25 tex $100 \%$ PES

\begin{tabular}{|c|c|c|c|c|c|c|}
\hline $\begin{array}{c}\text { Weft density } \\
\text { (threads/cm) }\end{array}$ & 12 & 14 & 16 & 18 & 20 & 22 \\
\hline $\begin{array}{c}\text { Rmax } \\
(\mathrm{cN} / \text { thread })\end{array}$ & 13 & 22 & 31 & 40 & 52 & 55 \\
\hline $\begin{array}{c}\text { Standard } \\
\text { deviation }\end{array}$ & 3 & 2 & 3 & 2 & 2 & 4 \\
\hline $\begin{array}{c}95 \% \\
\text { confidence } \\
\text { interval }\end{array}$ & 2 & 1 & 2 & 1 & 1 & 3 \\
\hline
\end{tabular}

Table 3. The values of maximum weaving resistance

\begin{tabular}{|c|c|c|c|c|c|c|}
\hline \multicolumn{7}{|c|}{ Material: $2 \times 25$ tex 100\% VS } \\
\hline $\begin{array}{c}\text { Weft density } \\
\text { (threads/cm) }\end{array}$ & 12 & 14 & 16 & 18 & 20 & 22 \\
\hline $\begin{array}{c}\text { Rmax } \\
(\mathrm{cN} / \text { thread) }\end{array}$ & 17 & 24 & 38 & 54 & 68 & 75 \\
\hline $\begin{array}{c}\text { Standard } \\
\text { deviation }\end{array}$ & 2 & 2 & 3 & 2 & 2 & 2 \\
\hline $\begin{array}{c}\text { 95\% } \\
\text { confidence } \\
\text { interval }\end{array}$ & 2 & 1 & 2 & 1 & 1 & 1 \\
\hline
\end{tabular}

\section{Conclusion}

The block diagram below shows maximum values of weaving resistance including an confidence interval. The figures shows that in the region of lower weft densities the maximum values of weaving resistance of PES and VS materials do not differ a great deal. Larger differences were observed in the region of higher weft densities. 
Therefore it can be assumed that the setting of the required weft density based on pure geometric parameters (see Introduction of this article) is reliable in the region of lower and medium weft densities. With higher weft densities, maximum weaving resistance depends on the material used, and hence variations in the achieved weft density for different materials can be assumed. In the region of extremely high weft densities, it is probably advisable to set them on the basis of force quantities in the beat up process.

Figure 7. Tensile forces in warp and in fabric as a function of time, material: PES, warp density 18 threads $/ \mathrm{cm}$

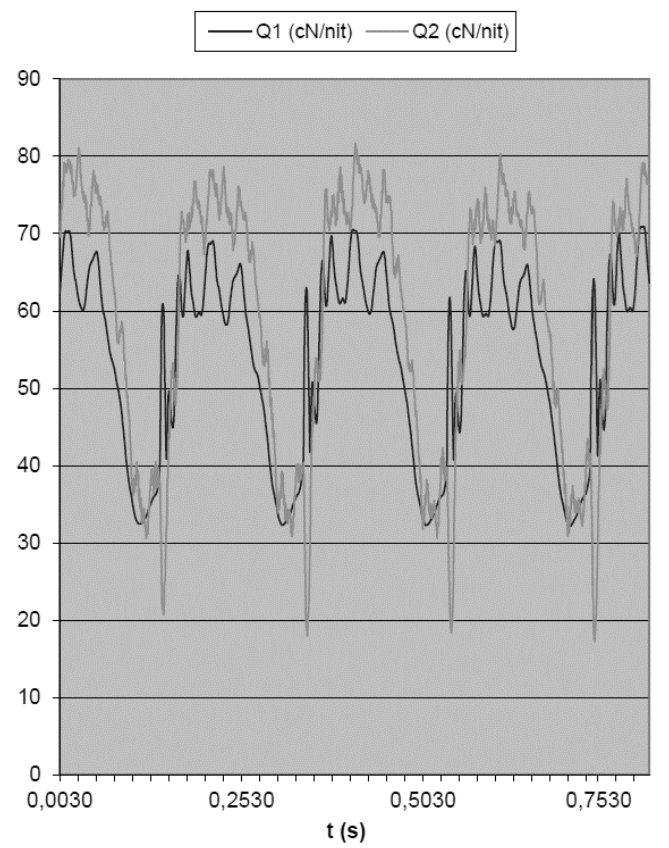

Figure 8. Weaving resistance as a function of time, material: PES, warp density: 18 threads/cm

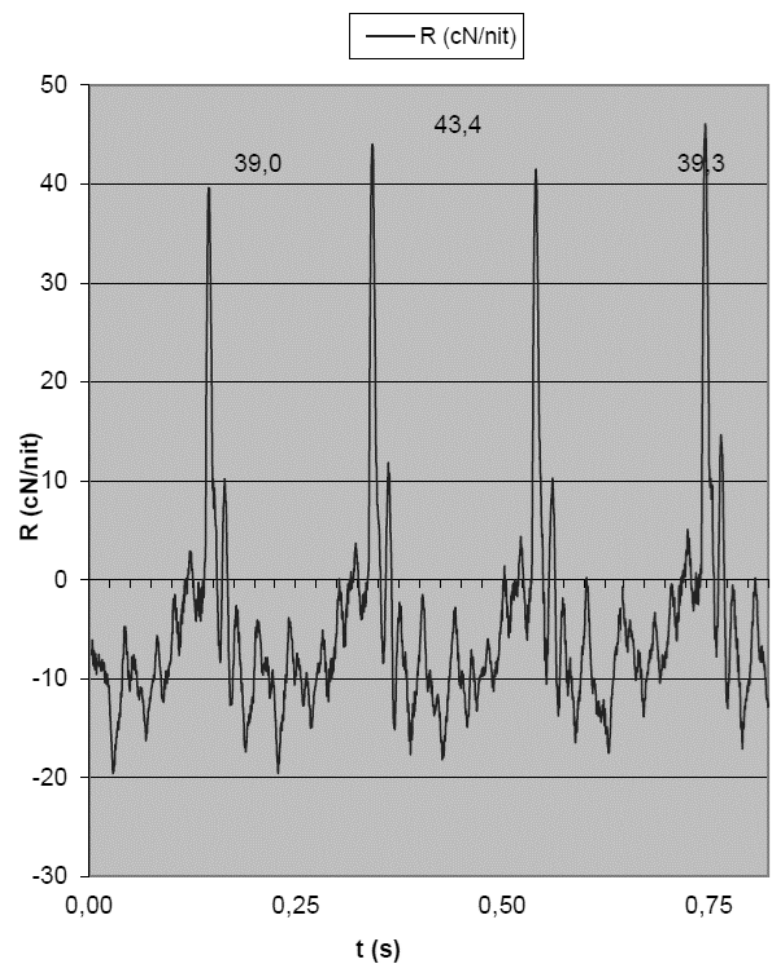

Figure 9: Maximum values of weaving resistance

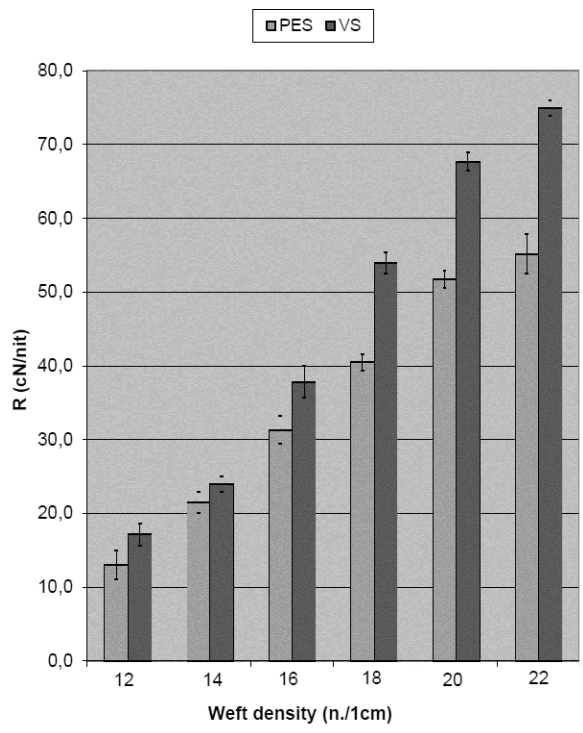

Acknowledgement: This publication was written at the Technical University of Liberec, Faculty of Mechanical Engineering with the support of the Institutional Endowment for the Long Term Conceptual Development of Research Institutes, as provided by the Ministry of Education, Youth and Sports of the Czech Republic in the year 2015.

\section{References}

1. Klouček, P., Škop, P.: Použití měřícího zařízení waweon k optimálnímu seřizení textilních, zejména tkacích strojů, 25th International conference quo vadis textrinum, pages: 50-59, 27.4-29.4.2004, NMC spol. s.r.o, Žilina, Slovakia, 2004

2. Morton, W. E. ; Hearle, J. W. S.: Physical properties of textile fibres, Manchester \& London, The Textile Institute Butterworths 1962.

3. Technical University of Liberec. Zařízení $\mathrm{k}$ měření tkacího odporu na tkacím stroji. Tumajer, P., Bílek, M. Int D 03 D 49/04. Čzech republic. Patent 303018

4. Tumajer P., Ursíny P., Bílek M., Moučková E.; Research Methods for the Dynamic Properties of Textiles. FIBRES \& TEXTILES in Eastern Europe 2011, Vol. 19, No. 5 (88) pp. 33-39.

5. Dvorak, J.; Bílek, M; Tumajer, P.: Vývojové trendy tkacích stroju, available from http://tkani.tul.cz/, ACCESSED 2015-03-09.

6. Nosek, S. At All: Solution of dynamics of weaving process and building the laboratory of diagnostics and measurements of textile machines. International journal of clothing science and technology, 10 (6), PP. 49-51.1998.

7. Tumajer, P., Ursíny, P., Bílek, M., Mouckova, E., Pokorna M.: Influence of structure of the yarn on mechanical characteristics of yarns exposed to dynamic stress, Autex Research Journal, Volume 12, Issue 2, June 2012, Pages 44-49.

8. Pustka M., Kloucek P., Škop P.: Waweon Instrument for dynamic measurement and analysis of threadand warp tension forces. Melliand International, March 2008. PP. 40-41. 